\title{
THE MAGGOT: AS A SUSTAINABLE SOLUTION OF ORGANIC WASTE MANAGEMENT AND ANIMAL FEEDING NEEDS
}

\author{
Yopi Harahap \\ Institut Pertanian Bogor, Bogor City, West Java, Indonesia \\ yopiharahap13@gmail.com
}

\begin{abstract}
Maggot comes from the Black Soldier Fly insect which is very active in eating a variety of organic waste. Maggot is able to process organic waste up to $52.2 \mathrm{~kg}$ per day. Indonesian waste dominated by organic species is 40 million tons in 2019 where $17.94 \%$ is produced by traditional markets (7 million tons). Based on BPS data, Traditional markets produce 1 ton of waste per day. By the ability of maggot to process waste, a $60 \times 40$ meter building is needed. Aside from being an organic waste solution but also as a producer of maggot with high protein, maggot flour and compost, it will add economic value. Organic waste production in Indonesia which continues to increase has the potential for maggot production to be continuous so that it can replace fish meal or conventional animal feed in terms of continuity. Maggot has a crude protein content of $42 \%$ so it is very good as a substitute for fish meal which is always imported. Maggot is also thought to have potential as a substitute for the MBM ration. Research shows that maggot flour can replace $75 \%$ of fish meal as an abdominal ration. The compost produced by maggot also has a greater NPK value than Em4 and cow dung, so that it has the potential to become a quality NPK fertilizer. It can be concluded maggot as an organic waste solution and potentially as a substitute for conventional sustainable feed.
\end{abstract}

Keywords: Maggot, organic waste, animal feeding.

\section{PENDAHULUAN}

Maggot berasal dari serangga Black Soldier Fly (Hermatia illucens), serangga ini dapat ditemukan di seluruh belahan dunia. Maggot atau disebut belatung merupakan fase dalam bentuk larva. Larva jenis ini sangat aktif memakan berbagai bahan organik seperti buahbuahan, sayuran, sampah pasar, sampah dapur, limbah ikan, serta kotoran hewan ternak. Selagi larva memakan sampah tersebut, mereka akan menghancurkan bahan organik dan melakukan proses metabolisme terhadap nutrisi sehingga menjadi biomassa larva. Siklus hidup maggot/larva berlangsung selama 18 hari sedangkan untuk siklus sebagai lalat dewasa berlangsung 9 hari mulai dari kawin hingga bertelur [1]. Siklus hidup sebagai larva 2 kali lebih lama dibanding siklus lalat, hal ini merupakan suatu keuntungan dimana sebagian besar hidupnya untuk mengurai sampah organik. Oleh sebab itu, maggot bisa dijadikan sebagai salah satu alternative solusi dalam penanggulangan sampah di Indonesia.

\section{METODE PENELITIAN}

Kerangka yang berukuran $1,5 \times 1$ meter terpasang 42 wadah $(40 \times 60 \times 17 \mathrm{~cm})$ yang berisi masing-masing 10.000 maggot mampu mengelolah sampah organik sebanyak 630kg selama 12 hari atau $52.2 \mathrm{~kg}$ perhari [2]. Berdasarkan data Sistem Informasi Pengolahan Nasional [3] pada tahun 2019 terdapat 67 juta ton sampah, yang didominasi jenis sampah organik mencapai $60 \%$ (40 juta ton) yang berasal dari sampah rumah tangga $38.36 \%$ (15 juta ton) dan 
pasar tradisional 17.94\% (7 juta ton). Berdasarkan data Badan Pusat Statistik [4] terdapat 14.812 pasar tradisional di seluruh Indonesia yang memproduksi sampah organik. Dari data tersebut dapat disimpulkan bahwa setiap pasar tradisonal memproduksi sampah organik mencapai 1 ton perhari. Penanganan sampah organik untuk setiap pasar dibutuhkan luas bangunan 60 x 40 meter untuk mengubah sampah menjadi biomasa maggot dan kompos. Hal ini merupakan salah satu solusi untuk penanganan sampah organik pasar tradisonal. Karena hal ini tidak berbeda jauh dengan pembangunan bank sampah yang berada di seluruh Indonesia, yang merupakan program pemerintah untuk penanganan sampah organik [5]. Bank sampah sendiri sudah tersebar di 34 provinsi atau 219 kabupaten/kota tahun 2017. Selain mengelola sampah, bank sampah berhasil memperkerjakan 168.128 orang [5]. Begitu juga dengan penerapan bank sampah maggot di setiap pasar akan mampu menangani sampah organik dan membuka lapangan pekerjaan. Bahkan pemerintah depok, Dinas Lingkungan Hidup dan Kebersihan (DLHK) sudah memanfaatan magot atau belatung dari lalat hitam atau Black Soldier Fly sebagai salah satu pengelola sampah organik. Sedangkan di Sukabumi, terdapat Bank Sampah Maggot yang dikelola incubie farm dimana setiap sampah organik diberikan harga. Disamping kemampuan maggot sebagai solusi penanganan organik, maggot memiliki nilai ekonomi yang lebih seperti protein maggot yang dihasilkan mencapai $40 \%$ yang baik untul pakan ternak (Tabel 1). Kompos yang dihasilkan maggot juga memiliki nilai NPK yang lebih tinggi dibanding kotoran sapi dan probiotik (EM4), dikatahui bahwa nilai NPK yang tinggi akan dapat menyuburkan tanah [6].

Tabel 1. Kandungan nutrisi maggot

\begin{tabular}{lrlr}
\hline \multicolumn{1}{c}{ Asam Amino Esensial } & & \multicolumn{2}{c}{ Mineral dan lain lain } \\
\hline Methionone & 0,83 & $\mathrm{P}$ & $0,88 \%$ \\
Lysine & 2,21 & $\mathrm{~K}$ & $1,16 \%$ \\
Leucin & 2,61 & $\mathrm{Ca}$ & $5,36 \%$ \\
Isoleucine & 1,51 & $\mathrm{Mg}$ & $0,44 \%$ \\
Histidene & 0,96 & $\mathrm{Mn}$ & $348 \mathrm{ppm}$ \\
Phenyllalanine & 1,49 & $\mathrm{Fe}$ & $776 \mathrm{ppm}$ \\
Valine & 2,23 & $\mathrm{Zn}$ & $271 \mathrm{ppm}$ \\
I-Arginine & 1,77 & Protein Kasar & $43,20 \%$ \\
Threonine & 1,41 & LemakKasar & $28,00 \%$ \\
Tryptopan & 0,59 & Abu & $16,60 \%$ \\
\hline
\end{tabular}

*Newton et al, 2005 [7]

Tabel 2. Hasil rataan kadar unsur hara makro pada setiap biodikomposer

\begin{tabular}{|c|c|c|c|c|c|}
\hline \multirow{2}{*}{ Jenis Biodekomposer } & \multicolumn{5}{|c|}{ Kadar unsur hara makro (\%) } \\
\hline & $\mathrm{N}$ & $\mathrm{P}$ & $\mathrm{K}$ & $\mathrm{Ca}$ & $\mathrm{Mg}$ \\
\hline Maggot & 2,74 & 0,88 & 6,6 & 1,2 & 0,23 \\
\hline EM4 & 1,44 & 0,02 & 0,98 & 0,67 & 0,27 \\
\hline Kotoran Sapi & 0,89 & 0,01 & 0,38 & 0,13 & 0,04 \\
\hline
\end{tabular}

Monita L, 2017

\section{HASIL DAN PEMBAHASAN}

Berdasarkan hasil riset J. K Tomberlin dan D. C. Sheppard [1], $900 \mathrm{~kg}$ sampah organik menghasilkan 1.6 juta larva yang menghasilkan $45 \mathrm{~kg}$ protein dan $180 \mathrm{~kg}$ kompos. Hasil riset ini tentunya maggot memiliki potensi sebagai subtitusi pakan ternak konvensional dari segi kualitas dan kuantitas. Disamping sampah organik Indonesia yang terus meningkat menjadikan maggot berpotensi diproduksi secara kontinu yang bakal menggantikan pakan ternak konvensional seperti tepung ikan dan Meat Meal Bone (MBM). Sesuai dengan pernyataan Dosen IPB, Dr Hartono maggot berpotensi menggantikan MBM yang selalu di impor sebagai bahan ransum untuk pakan ternak [8]. Di dukung oleh penelitian [9] dimana subtitusi tepung maggot sebesar 75\% dapat meggantikan tepung ikan untuk 
ransum lemak abdomen unggas. Dari segi kualitas dan kuantitas berdasarkan penelitian menyatakan maggot memiliki potensi sebagai pakan subtitusi untuk ikan lele dimana Penggunaan pelet $50 \%$ dan $50 \%$ maggot dapat menghemat biaya pakan sebesar $22.74 \%$ [10]. Selain pemberian maggot dalam bentuk larva yang dipanen umur 12-14 hari setelah telur menetas, maggot dapat diolah menjadi tepung maggot sehingga memiliki umur simpan yang lebih lama. Tepung maggot ini yang akan memiliki potensi sebagai pengganti tepung ikan yang selalu import yang mencapai 4000 ton pada tahun 2016 . Tepung maggot dijadikan pelet dengan campuran komposisi pakan seperti (Kedelai, Sorgum dan jagung) untuk membuat campuran yang memenuhi kebutuhan pakan ternak seperti ikan, unggas dan lain-lain. Berdasarkan penelitian, [11] pemberian pakan maggot dalam bentuk larva dan dalam bentuk pelet menunjukkan hasil yang sama karena memiliki kandungan kalsium yang sama. Serta dapat memenuhi kebutuhan nutrisi pakan ikan ranbow kurumoi.

\section{KESIMPULAN}

Dengan kemampuan maggot memakan atau mengurai sampah organik sebesar $52 \mathrm{~kg}$ perhari, dapat disimpulkan maggot sebagai solusi pengelolaan sampah organik di Indonesia khususnya pasar tradisional. Kandungan protein yang tinggi hingga $42 \%$ dan kemampuan berkembang biaknya sangat cepat dan kontiniunitas seiring dengan selalu bertambahnya sampah organik membuat maggot memiliki potensi sebagai pengganti pakan ternak konvensional dan bahan bakunya seperti tepung ikan dan MBM yang masih impor. Hasil samping maggot yang berupa kotoran/kompos memiliki nilai NPK yang lebih tinggi dibanding EM4 dan kotoran sapi berpotensi sebagai pengganti pupuk organik.

\section{DAFTAR PUSTAKA}

[1] J. K Tomberlin, D. C. Sheppard, Factors influencing mating and oviposition of black soldier flies (Diptera: Stratiomyidae) in a colony, Journal of Entomological Science. 37 (2006) 345-352. https://doi.org/10.18474/07498004-37.4.345

[2] B.M.A. Dortmans, S. Diener, B.M. Verstappen C. Zurbrugg, Proses Pengolahan Sampah Organik dengn Black Soldier Fly (BSF) (Trans Dwi Cahyani Octaviani), Eawag - Swiss Federal Institute of Aquatic Science and Technology, 2017.

[3] System Informasi Pengolahan Sampah Nasional. http://sipsn.menlhk.go.id/, 2020 (accessed 29 January 2020).

[4] Profil Pasar Tradisional, Pusat Perbelanjaan, dan Toko Modern Tahun 2018, Badan Pusat Statistik RI, Jakarta, 2018

[5] Statistik Lingkungan Hidup Indonesia, Pengolahan Sampah di Indonesia 2018.

[6] L. Monita, Biokonversi Sampah Organik Menggunakan Larva Black Soldier Fly (Hermatia illucens) dan EM4 dalam Rangka Menunjang Pengolahan Sampah Berkelanjutan. Tesis magister. Depatemen Pengolahan Sumber Daya Alam dan Lingkungan Fakultas Pascasarjana Institut Pertanian Bogor, Bogor, 2017.

[7] G. L Newton., D. C. Sheppard, D. W. Watson, G. J Burtle, C. R. Dove, J. K. Tomberlin, \& E. E. Thelen, The black soldier fly, Hermetia illucens, as a manure management/ resource recovery tool, In Proceedings of the Symposium on the State of the Science of Animal Manure and Waste Management. San Antonio, (2005).

[8] Pakan Ternak Alternatif dari Maggot. http://intp.fapet.ipb.ac.id/?p=1816s, 2018 (accessed 29 January 2020).

[9] Rumundor G, K. Maaruf, Y.R.L. Tulung, Wolayan, Pengaruh Penggantian Tepung Ikan dengan Tepung Maggot Black Soldier (Hermatia illucens) dalam Ransum Terhadap Presentase Karkas dan Lemak Abdomen Broiler, J. Zootek. 36 (2016) 131 - 138. https://ejournal.unsrat.ac.id/index.php/zootek/article/view/10452. 
[10] R.U.A Fauzi, E.R.N Sari, Analisis Usaha Budidaya Maggot Sebagai Alternatif Pakan Lele, J.Indsutria. Teknologi dan Manajemen Agroindustri. 7 (2018) 39-46. https://pdfs.semanticscholar.org/b2b0/070781118c955571138fc3ca60610c9b95f7.pdf

[11] A. Priyadi, Z. I. Azwar, I. W. Subamia, S. Hem, Pemanfaatan Maggot Sebagai Pengganti Tepung Ikan dalam Pakan Buatan untuk Benih Ikan Balashark (Balanthiocheilus melanopterus Bleeker), J. Ris. Akuakultur. 4 (2009) 367-375. http://ejournalbalitbang.kkp.go.id/index.php/jra/article/view/2496 